\title{
HQNO-sensitive NADH:DCIP Oxidoreductase of a Pathogenic Bacillus cereus Causing $\beta$-Hemolysis
}

\author{
Young Jae Kim* and Ki Tae Park' \\ Department of Microbiology, Changwon National University, Sarim-dong, Changwon, Kyungnam 641-773, Korea \\ ${ }^{1}$ Ki Tae Park Korean Medicine Clinic, Sangnam-dong, Changwon, Kyungnam 641-773, Korea
}

Received March 8, 2006 / Accepted April 11, 2006

\begin{abstract}
Membranes prepared from Bacillus cereus KCTC 3674, grown aerobically on a complex medium, oxidized NADH exclusively, whereas deamino-NADH was little oxidized. The respiratory chain-linked $\mathrm{NADH}$ oxidase system exhibited an apparent $\mathrm{K}_{\mathrm{m}}$ value of about $65 \mu \mathrm{M}$ for $\mathrm{NADH}$. Interestingly, the activity of NADH:DCIP oxidoreductase on NADH oxidase system was decreased remarkably by $\mathrm{Na}^{+}$ or $\mathrm{K}^{+}$, and its optimal $\mathrm{pH}$ was 5.5. The activity of NADH:DCIP oxidoreductase was very resistant to the respiratory chain inhibitors such as rotenone, capsaicin, and $\mathrm{AgNO}_{3}$, whereas it was inhibited by about $40 \%$ with $40 \mu \mathrm{M}$ 2-heptyl-4-hydroxyquinoline-N-oxide (HQNO). From the results, we suggest the possibility that the aerobic respiratory chain-linked NADH oxidase system of $B$. cereus KCTC 3674 may possess the HQNO-sensitive NADH:DCIP oxidoreductase lacking an energy coupling site.
\end{abstract}

Key words - Bacillus cereus KCTC 3674, aerobic respiratory chain, NADH:DCIP oxidoreductase

\section{Introduction}

Although the NABH dehydrogenases (NDH) in the bacterial respiratory chains are referred to as NADH:ubiquinone oxidoreductase, many bacteria have been known to possess quinones other than ubiquinone[2]. Thus, the name NADH:quinone oxidoreductase in bacteria seems more appropriate than NADH:ubiquinone oxidoreductase.

Three types of NADH:quinone oxidoreductases in the respiratory chain of bacteria have been reported[14]. They are the $\mathrm{H}^{+}$-translocating $\mathrm{NADH}$ :quinone oxidoreductase (designated NDH-1), the $\mathrm{Na}^{+}$-translocating NADH:quinone oxidoreductase (designated $\mathrm{Na}^{+}-\mathrm{NDH}$ ), and the NADH: quinone oxidoreductase lacking an energy coupling site (designated $\mathrm{NDH}-2$ ). In general, $\mathrm{NDH}-1$ or $\mathrm{Na}^{+}-\mathrm{NDH}$ reacts with deamino-NADH as well as with NADH, shows high affinities for $\mathrm{NADH}$, and possesses an energy coupling site[4,8]. In contrast, NDH-2 reacts very little with deamino-NADH, but with NADH without any energy coupling site, and shows low affinities for $\operatorname{NADH}[4,7,8]$. Escherichia coli[8], Vibrio alginolyticus[9,10], and Thermus thermophilus HB-8[13] are known to possess two different types of NADH:quinone oxidoreductases. Zymomonas mobilis is known to possess only NADH:quinone oxidoreductase lacking the energy coupling site[7].

\section{*Corresponding author}

Tel : +82-2-55-279-7464, Fax : +82-55-279-7460

E-mail : yjkim@changwon.ac.kr
Respiratory chain inhibitors have proved to be a useful tool for probing the mechanism of electron transfer and proton or sodium translocation in the respiratory chain. Generally, NDH-1 is inhibited by the respiratory inhibitors rotenone and capsaicin, whereas NDH-2 is only slightly inhibited by these inhibitors[13,14]. Interestingly, $\mathrm{Na}^{+}-\mathrm{NDH}$ is known to be very resistant to rotenone and capsaicin[14], but highly sensitive to 2-heptyl-4-hydroxyquinoline- $\mathrm{N}$-oxide[10] and $\mathrm{AgNO}_{3}[1]$.

Takao Yagi showed that the respiratory inhibitor capsaicin inhibited $\mathrm{H}^{+}$-translocating $\mathrm{NADH}$ :quinone oxidoreductases, and did not inhibit the NADH oxidase and NADH:quinone oxidoreductase of Bacillus subtilis[12]. To date, little detailed study has been done on the enzymatic and energetic properties of the aerobic respiratory chain-linked NADH oxidase system in the genus Bacillus. $B$. cereus produces several extracellular hemolysins, which are considered potential factors of virulence of the opportunistic pathogen[11]. In this paper, we report the results for enzymatic properties of the NADH:DCIP oxidoreductase on the aerobic respiratory chain-linked NADH oxidase system of B. cereus KCTC 3674 .

\section{Materials and Methods}

\section{Bacterial strain and conditions}

The bacterial strain used in this study was B. cereus KCTC $3674[3,4,5]$. The bacterium was grown aerobically at 
$37^{\circ} \mathrm{C}$ in liquid media containing $0.5 \%$ polypeptone and $0.5 \%$ yeast extract in $50 \mathrm{mM}$ Tris- $\mathrm{HCl}$ buffer $(\mathrm{pH} 7.5)$. Preculture grown overnight was used to inoculate the main culture to give a turbidity of approximately 0.03 .

\section{Preparation of membranes from $B$. cereus KCTC 3674}

For the preparation of membranes from B. cereus KCTC 3674 , the protoplast formation was carried out at $37^{\circ} \mathrm{C}$. Cells harvested in logarithmic growth phase were suspended in $50 \mathrm{mM}$ potassium phosphate $(\mathrm{pH} 7.5)$ containing $5 \mathrm{mM}$ EDTA at a concentration of $1 \mathrm{~g}$ (wet weight) per $80 \mathrm{ml}$. Lysozyme was added at a concentration of $300 \mu$ $\mathrm{g} / \mathrm{ml}$ (freshly prepared). The mixture was incubated for 30 $\mathrm{min}$, after which the protoplasts were harvested by centrifugation at $14,000 \times \mathrm{g}$ for $30 \mathrm{~min}$. Protoplasts were washed once in $50 \mathrm{mM}$ potassium phosphate $(\mathrm{pH} 7.5)$ containing $5 \mathrm{mM}$ EDTA, and centrifuged at $14,000 \times \mathrm{g}$ for $30 \mathrm{~min}$ at $4^{\circ} \mathrm{C}$. Washed protoplasts were resuspended in $50 \mathrm{mM}$ potassium phosphate ( $\mathrm{pH} 7.5$ ) containing $5 \mathrm{mM}$ EDTA to give a concentration of $20 \mathrm{ml} / \mathrm{g}$, and protoplast suspensions were passed through a French pressure cell twice at 25,000 psi. Unbroken cells and cell debris were removed by centrifugation at $10,000 \times \mathrm{g}$ for $10 \mathrm{~min}$ at $4^{\circ} \mathrm{C}$, and the supernatant was centrifuged at $120,000 \times \mathrm{g}$ for $2 \mathrm{~h}$ at $4^{\circ} \mathrm{C}$ to sediment the membrane fraction. A membrane pellet was washed in $50 \mathrm{mM}$ potassium phosphate $(\mathrm{pH} 7.5)$ containing $5 \mathrm{mM}$ EDTA. After sedimentation at $120,000 \times \mathrm{g}$ for

$2 \mathrm{~h}$ at $4^{\circ} \mathrm{C}$, inverted membrane vesicles were rewashed in $50 \mathrm{mM}$ potassium phosphate ( $\mathrm{pH} 7.5$ ) containing $10 \%$ glycerol. Membranes were resuspened in $50 \mathrm{mM}$ potassium phosphate $(\mathrm{pH} 7.5)$ containing $10 \%$ glycerol at a protein concentration of about $25 \mathrm{mg} / \mathrm{ml}$, and stored at $-80^{\circ} \mathrm{C}$.

\section{Measurement of enzyme activities}

The activity of the NADH oxidase was measured at $37^{\circ} \mathrm{C}$ from a decrease in $\mathrm{A}_{340}$ by using varian Cary $3 \mathrm{E}$ spectrophotometer. The assay mixture of NADH oxidase contained $125 \mu \mathrm{M}$ NADH or deamino-NADH in $2 \mathrm{ml}$ of 50 $\mathrm{mM}$ Tris- $\mathrm{HCl}(\mathrm{pH} 8.5)$ containing $0.1 \mathrm{M} \mathrm{KCl}$. The assay was started by addition of $200 \mathrm{\mu g}$ of membrane protein. Activity was calculated by using a millimolar extinction coefficient of 6.22 . The assay mixture for NADH:DCIP oxidoreductase contained $50 \mu \mathrm{g}$ of membrane protein, $30 \mathrm{mM}$ $\mathrm{KCN}$, and $100 \mu \mathrm{M} \mathrm{DCIP}$ (2,6-dichlorophenol-indophenol) in $2 \mathrm{ml}$ of $50 \mathrm{mM}$ MES-KOH (pH 5.5). The reaction of the NADH:DCIP oxidoreductase was started by the addition of
$125 \mu \mathrm{M}$ NADH. The NADH:DCIP oxidoreductase activity was measured at $600 \mathrm{~nm}$, and was calculated by using a millimolar extinction coefficient of 16.5 .

\section{Protein determination}

Protein was measured by Bio-Rad protein assay, based on the method of Bradford. Bovine serum albumin was used as a standard.

\section{Results}

\section{Enzymatic properties of the membrane-bound NADH oxidase}

The effects of salts and $\mathrm{pH}$ on the NADH oxidase activity were examined with membranes prepared from $B$. cereus KCTC 3674. As shown in Fig. 1, the membranes oxidized NADH (O), but very little deamino-NADH $(O)$ as a substrate. The rate of NADH oxidation was slightly activated by monovalent cations including $\mathrm{Na}^{+}$and $\mathrm{K}^{+}$, but was little activated by $\mathrm{Li}^{+}$(data not shown). The maximum activity of NADH oxidase was obtained in the presence of $0.1 \mathrm{M} \mathrm{NaCl}$ or $\mathrm{KCl}$. The optimal $\mathrm{pH}$ for NADH oxidation in the presence of $0.1 \mathrm{M} \mathrm{NaCl}$ was 8.5 (data not shown).

The respiratory chain-linked NADH oxidase system exhibited an apparent $K_{m}$ value of about $65 \mu \mathrm{M}$ for NADH (Fig. 2). In order to examine the enzymatic properties of NADH:quinone oxidoreductase of $B$. cereus KCTC 3674 , an artificial electron acceptor 2,6-dichlorophenol-indophenol (DCIP) was introduced.

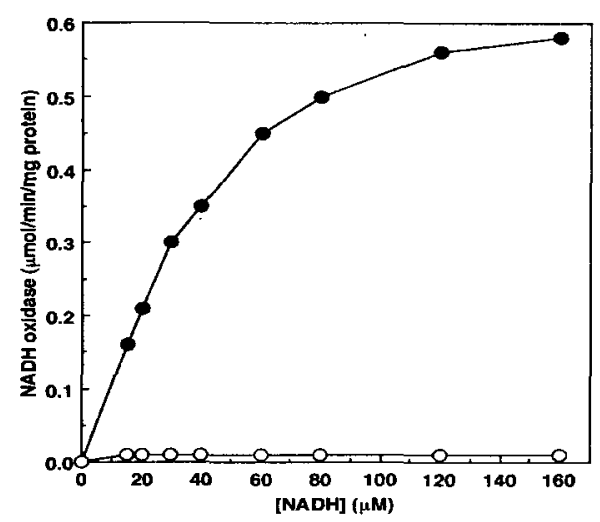

Fig. 1. Ability of NADH oxidase to oxidize NADH or deamino-NADH. The activities of NADH and deamino-NADH oxidases were measured in $2 \mathrm{ml}$ of $50 \mathrm{mM}$ Tris- $\mathrm{HCl}(\mathrm{pH} 8.5$ ) containing $0.1 \mathrm{M} \mathrm{KCl}$ and different concentrations of NADH (O) or deamino-NADH (O). The assay was started by addition of membrane suspensions containing about $200 \mu \mathrm{g}$ of protein at $37^{\circ} \mathrm{C}$. 


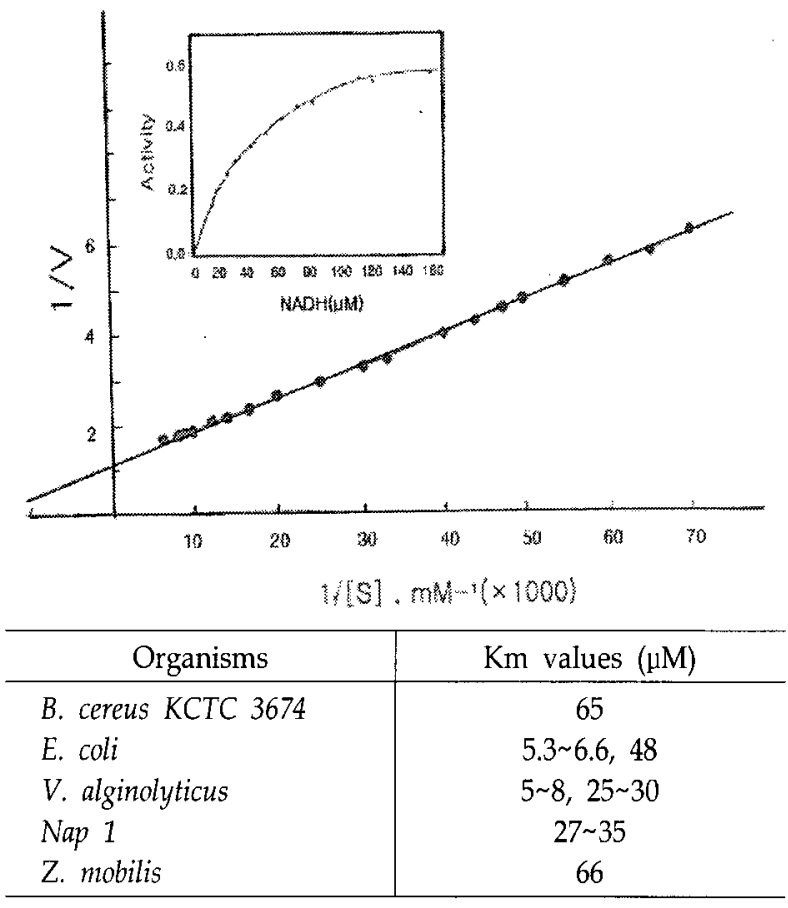

Fig. 2. A Lineweaver-Berk plot of the NADH oxidase activity. The $K_{m}$ values of $B$. cereus KCTC $3674, V$. alginolyticus, and Nap 1 which is a $\mathrm{Na}^{+}$pump-defective mutant of $V$. alginolyticus [9] were measured in this study.

The effects of salts, $\mathrm{pH}$, and respiratory inhibitors on the activity of the NADH:DCIP oxidoreductase

The activity of NADH:DCIP oxidoreductase was remarkably reduced by $\mathrm{Na}^{+}$and $\mathrm{K}^{+}$(Fig. 3A), and was, also, prominently reduced with an increase in the value of $\mathrm{pH}$ (Fig. 3B).
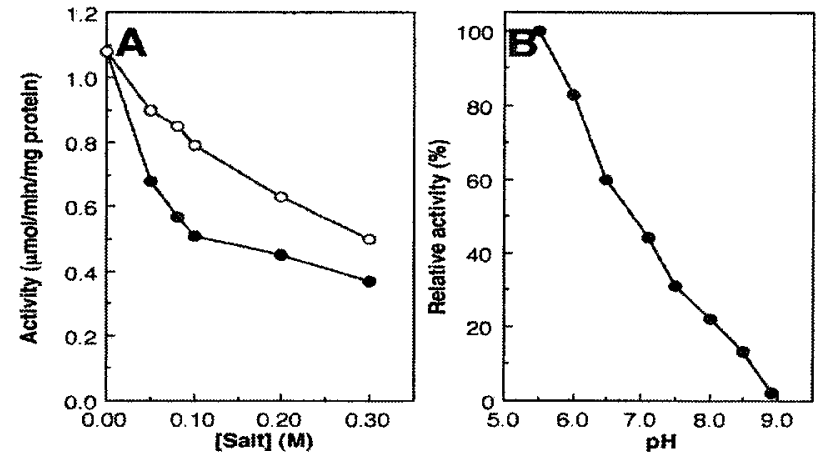

Fig. 3. Effects of salts and $\mathrm{pH}$ on the activity of NADH:DCIP oxidoreductase. (A) The assay mixture of NADH:DCIP oxidoreductase $(2 \mathrm{ml})$ contained $50 \mathrm{mM}$ MES- $\mathrm{KOH}(\mathrm{pH}$ 5.5), $50 \mu \mathrm{g}$ of membrane protein, $30 \mathrm{mM} \mathrm{KCN}, 100 \mu \mathrm{M}$ DCIP, and various concentrations of $\mathrm{NaCl}(\mathbf{O})$, or $\mathrm{KCl}$ (O), (B) The activity of NADH:DCIP oxidoreductase was determined at various $\mathrm{pHs}$. Buffers used at $50 \mathrm{mM}$ was MES-KOH (pH 6 to 6.5) and Tris- $\mathrm{HCl}$ (pH 7.1 to 8.9). All assays were started by addition of $125 \mu \mathrm{M}$ NADH at $37^{\circ} \mathrm{C}$.
The respiratory inhibitor 2-heptyl-4-hydroxyquinoline- $\mathrm{N}$-oxide(HQNO), which acts at the bytochromes and also inhibits the $\mathrm{Na}^{+}$-translocating NADH:quinone oxidoreductase, inhibited the activity of NADH:DCIP oxidoreductase by about $40 \%$ at a concentration of $100 \mu \mathrm{M}$ (Fig. $4 \mathrm{~A}$ ). Rotenone and capsaicin, which inhibit the energy-transducing NADH: quinone oxidoreductase, inhibited the activity by about $10 \%$ at a concentration of $100 \mu \mathrm{M}$ and $300 \mu \mathrm{M}$, respectively (Fig. $4 B$ and $4 \mathrm{C})$.

\section{Effect of $\mathrm{Ag}^{+}$on the enzyme activities of $\mathrm{NADH}$ oxidase system}

$\mathrm{AgNO}_{3}$ is known to inhibit $\mathrm{Na}^{+}$-translocating $\mathrm{NADH}$ : quinone oxidoreductase[1]. As shown in Fig. 5, the membrane-bound $\mathrm{NADH}$ oxidase activity was highly sensitive
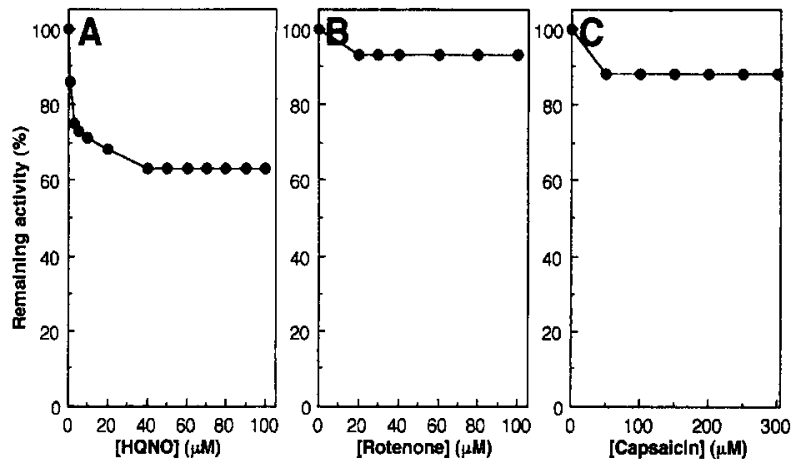

Fig. 4. Effects of respiratory chain inhibitors on the NADH: DCIP oxidoreductase. The activity of NADH:DCIP oxidoreductase was measured with various concentrations of HQNO (A), rotenone (B), and capsaicin (C). The assay mixture of NADH:DCIP oxidoreductase contained $50 \mu \mathrm{g}$ of membrane protein, $30 \mathrm{mM} \mathrm{KCN}$, $100 \mu \mathrm{M}$ DCIP in $2 \mathrm{ml}$ of $50 \mathrm{mM}$ MES-KOH (pH 5.5). All assays were started by addition of $125 \mu \mathrm{M}$ NADH.

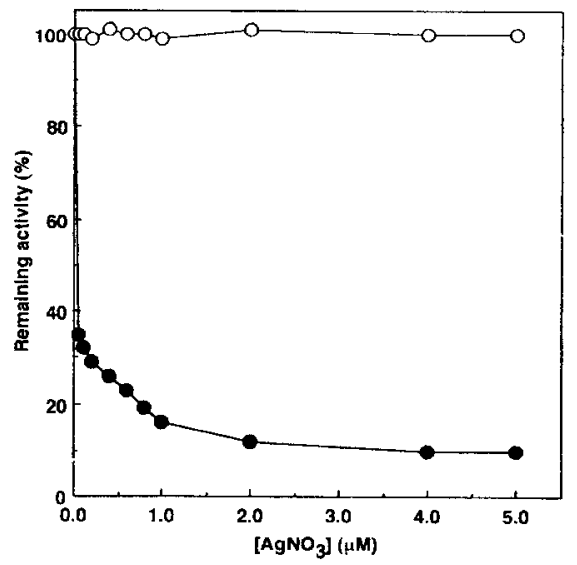

Fig. 5. Effect of $\mathrm{AgNO}_{3}$ on the enzyme activities of the NADH oxidase and NADH:DCIP oxidoreductase. NADH oxidase $(\mathbf{O})$ and NADH:DCIP oxidoreductase $(O)$. 
to $\mathrm{Ag}^{+}$. In contrast, the activity of NADH:DCIP oxidoreductase was not affected by $\mathrm{Ag}^{+}$at all.

\section{Discussion}

The results of this study show the possibility that the aerobic respiratory chain-linked NADH oxidase system of $B$. cereus KCTC 3674 may possess the enzymatic system lacking an energy coupling site.

Membranes prepared from B. cereus KCTC 3674 oxidized $\mathrm{NADH}$, but very little deamino-NADH as a substrate, and exhibited an apparent $K_{m}$ value of approximately $65 \mu \mathrm{M}$ for NADH. Generally, NADH:quinone oxidoreductase lacking an energy coupling site (NDH-2) oxidizes little deamino-NADH, and shows low affinities for NADH[7,8] (Fig. 2). The activities of NADH oxidase and NADH:ubiquinone-1 oxidoreductase of $B$. subtilis membranes are little affected by capsaicin[12]. In order to examine the enzymatic properties of NADH:quinone oxidoreductase of $B$. cereus KCTC 3674, an artificial electron acceptor 2,6-dichlorophenol-indophenol (DCIP) was introduced in this study. The activity of NADH:DCIP oxidoreductase of $B$. cereus KCTC 3674 was little affected by capsaicin and rotenone. $\mathrm{AgNO}_{3}$ and $\mathrm{HQNO}$ are known to be the potent inhibitors of $\mathrm{Na}^{+}$-translocating $\mathrm{NADH}$ :quinone oxidoreductase[1,10]. Interestingly, the NADH:DCIP oxidoreductase of B. cereus KCTC 3674 was sensitive to HQNO, whereas was not affected by $\mathrm{Ag}^{+}$at all. The membrane-bound $\mathrm{NADH}$ oxidase was highly sensitive to $\mathrm{Ag}^{+}$. Thus, it is suggested that $\mathrm{AgNO}_{3}$ does not inhibit the NADH:quinone oxidoreductase of $B$. cereus KCTC 3674 , but inhibit the quinol oxidase.

B. cereus KCTC 3674 vigorously excretes proteases into the extracellular environment $[3,6]$. Thus, it is very difficult to prepare the functional inverted membrane vesicles for energy measurement experiment. Due to the lack of a functional in vitro system, little detailed study has been done on the energetic experiments in the genus Bacillus. To further examine whether the aerobic respiratory chain of $B$. cereus KCTC 3674 generates energy or not, we will try the preparation of inverted membrane vesicles for a functional in vitro energy measurement system.

\section{Acknowledgments}

This work was financially supported by Changwon National University in 2005.

\section{References}

1. Asano, M., M. Hayashi, T. Unemoto and H. Tokuda. 1985. $\mathrm{Ag}^{+}$-sensitive $\mathrm{NADH}$ dehydrogenase in the $\mathrm{Na}^{+}$-motive respiratory chain of the marine bacterium Vibrio alginolyticus. Agric. Biol. Chem. (Biosci. Biotechnol. Biochem.) 49, 2813-2817.

2. Collins, M. D. and D. Jones. 1981. Distribution of isoprenoid quinone structural types in bacteria and their taxonomic implications. Microbiol. Rev. 45, 316-354.

3. Kim, S. S., Y. J. Kim and I. Rhee. 2001. Purification and characterization of anovel extracellular protease from Bacillus cereus KCTC 3674. Arch. Microbiol. 175, 458-461.

4. Kim, Y. J., S. Mizushima, and H. Tokuda. 1991. Fluorescence quenching studies on the characterization of energy generated at the NADH:quinone oxidoreductase and quinol oxidase segments of marine bacteria. I. Biochem. (Tokyo) 109, 616-621.

5. Kim, S. S., Y. Park, J. Lee, J. Yoon, Y. Shin, I. Rhee and Y. J. Kim. 1998. Taxonomic studies of the beta hemolysis-causing pathogen Bacillus cereus isolated from sea water. J. Microbiol. Biotech. 8, 67-73.

6. Kim, S. S., Y. Park, I. Rhee and Y. J. Kim. 2000. Influence of temperature, oxygen, $m$-chlorophenylhydrazone, cerulenin, and quinacrine on the production of extracellular proteases in Bacillus cereus. J. Microbiol. Biotech. 10, 103-106.

7. Kim, Y. J., K. Song and S. Rhee. 1995. A novel aerobic respiratory chain-linked NADH oxidase system in Zymomonas mobilis. J. Bacteriol. 177, 5176-5178.

8. Matsushita K, T. Ohnishi and R. Kaback. 1987. NADH:ubiquinone oxidoreductase of the Escherichia coli aerobic respiratory chain. Biochemistry 26, 7732-7737.

9. Tokuda, H. 1983. Isolation of Vibrio alginolyticus mutants defective in the respiration-coupled $\mathrm{Na}^{+}$pump. Biochem. Biophys. Res. Commun. 114, 113-118.

10. Tokuda, $\mathrm{H}$ and T. Unemoto. $1984 . \mathrm{Na}^{+}$is translocated at NADH:quinone oxidoreductase segment in the respiratory chain of Vibrio alginolyticus. J. Biol. Chem. 259, 7785-7790.

11. Turnbull, P. C. B. 1986. Pharmacology of Bacterial Toxins (Dorner F and Drews J, eds). Pergamon Press, Oxford. 397-448.

12. Yagi T. 1990. Inhibition by capsaicin of NADH-quinone oxidoreductases is correlated with the presence of energy-coupling site 1 in various organisms. Arch. Biochem. Biophys. 281(2), 305-311.

13. Yagi T, K. Hoh-nami and T. Ohnishi. 1998b. Purification and characterization of two types of NADH-quinone reductase from Thermus thermophilus HB-8. Biochemistry 27, 2008-2013.

14. Yagi T, T. Yano, S. D. Bernardo, A. Matsuno-Yagi. 1998a. Procaryotic complex I (NDH-1), an overview. Biochim. Biophys. Acta. 1364, 125-133. 
초록 : Beta hemolysis 유발 병원균 Bacillus cereus의 HQNO-sensitive NADH:DCIP oxidoreductase 김영재* 박기태 ${ }^{1}$

(창원대학교 자연과학대학 미생물학과, ${ }^{1}$ 박기태 한의원)

호기적으로 자란 Bacillus cereus KCTC 3674로 부터 조제된 막은 NADH만을 산화하고, deamino-NADH는 거 의 산화하지 않았다. 호흡쇄와 연계된 NADH oxidase계는 $\mathrm{K}_{\mathrm{m}}$ 값이 약 $65 \mu \mathrm{M}$ 이였다. NADH:DCIP oxidoreductase의 활성은 $\mathrm{Na}^{+}$또는 $\mathrm{K}^{+}$에 의해 감소되었다. 그 최적 $\mathrm{pH}$ 는 5.5 였다. NADH:DCIP oxidoreductase의 활성 은 rotenone, capsaicin, $\mathrm{AgNO}_{3}$ 와 같은 호흡저해제에는 매우 저항적이였지만, $40 \mu \mathrm{M} \mathrm{HQNO} \mathrm{(2-heptyl-4-hydrox-}$ yquinoline-N-oxide) 존재하에서는 약 $40 \%$ 저해되었다. 이들 결과로 부터, Bacillus cereus KCTC 3674의 호기적 호홉쇄와 연계된 NADH oxidase계는 energy coupling site가 결여된 HQNO-sensitive NADH:DCIP oxidoreductase를 소유하고 있는 것으로 추정된다. 